\title{
Calculation of organic matter and nutrients stored in soils under contrasting management regimes
}

\author{
B. H. Ellert ${ }^{1}$ and J. R. Bettany ${ }^{2}$ \\ ${ }^{1}$ Agriculture and Agri-Food Canada, Research Centre, P.O. Box 3000, Lethbridge, Alberta, Canada T1J 4B1;
2 Department of Soil Science, University of Saskatchewan, Saskatoon, Saskatchewan, Canada S7N 5A8:
Received 20 April 1994, accepted 3 May 1995.
}

Ellert, B. H. and Bettany, J. R. 1995. Calculation of organic matter and nutrients stored in soils under contrasting management regimes. Can. J. Soil Sci. 75: 529-538 Assessments of management-induced changes in soil organic matter depend on the methods used to calculate the quantities of organic $\mathrm{C}$ and $\mathrm{N}$ stored in soils. Chemical analyses in the laboratory indicate the concentrations of elements in soils, but the thickness and bulk density of the soil layers in the field must be considered to estimate the quantities of elements per unit area. Conventional methods that calculate organic matter storage as the product of concentration, bulk density and thickness do not fully account for variations in soil mass. Comparisons between the quantities of organic $\mathrm{C}, \mathrm{N}$, $\mathrm{P}$ and $\mathrm{S}$ in Gray Luvisol soils under native aspen forest and various cropping systems were hampered by differences in the mass of soil under consideration. The influence of these differences was eliminated by calculating the masses of $C, N, P$ and $S$ in an "equivalent soil mass" (i.e. the mass of soil in a standard or reference surface layer). Reassessment of previously published data also indicated that estimates of organic matter storage depended on soil mass. Appraisals of organic matter depletion or accumulation usually were different for comparisons among element masses in an equivalent soil mass than for comparisons among element masses in genetic horizons or in fixed sampling depths. Unless soil erosion or deposition had altered the mass of topsoil per unit area, comparisons among unequal soil masses were unjustified and erroneous. For management-induced changes in soil organic matter and nutrient storage to be assessed reliably, the masses of soil being compared must be equivalent.

Key words: Soil carbon, soil nitrogen, soil phosphorus, soil sulfur, carbon cycle, carbon storage, bulk density effects, Gray Luvisol, soil erosion

\begin{abstract}
Ellert, B. H. et Bettany, J. R. 1995. Calcul de la matière organique et des nutriments emmagasinés dans les sols conduits selon des régimes différents. Can. J. Soil Sci. 75: 529-538. L'évaluation des modifications de la matière organique du sol liées au mode de conduite dépend des méthodes utilisées pour calculer les quantités de $\mathrm{C}$ et de $\mathrm{N}$ organiques emmasinées dans le sol. Les analyses chimiques en laboratoire fournissent les concentrations des éléments présents dans le sol, mais on doit tenir compte de l'épaisseur et de la densité apparente des divers horizons, lorsqu'on veut évaluer la quantité de ces éléments par unité de surface. Les méthodes classiques, qui calculent les quantités de matière organique emmagasinées d'après des concentrations ainsi que d'après la densité apparente et l'épaisseur du sol, ne prennent pas pleinement en compte les variations touchant la masse du sol. Les comparaisons entre les quantités de C, N, P et S organique dans des Luvisol gris sous tremblaie naturelle et sous divers systèmes culturaux étaient gênées par les différences de masse de sol utilisées.L'effet de ces différences était éliminé en calculant les masses de $\mathrm{C}, \mathrm{N}, \mathrm{P}$ et $\mathrm{S}$ dans une masse de sol équivalente, c'est-à-dire la masse du sol dans une couche de surface standard ou témoin. Une réévaluation des données publiées a permis également de montrer que les calculs de la matière organique emmagasinée dépendent de la masse du sol. Les calculs des pertes ou de l'accumulation de matière organique différaient dans l'ensemble selon que les comparaisons portaient sur la masse des éléments mesurés dans une masse de sol équivalente ou dans des horizons génétiques ou dans une profondeur d'échantillonnage fixe. Sauf là où l'érosion du sol ou les dépôts de sol avaient modifié la masse de la couche arable par unité de surface, les comparaisons entre masses de sol inégales ne se justifiaient pas et étaient faussées. Pour pouvoir évaluer de façon fiable les modifications des quantités de matière organique et des nutriments liées aux modes de conduite du sol, il est nécessaire que les masses de sol comparées soient équivalentes.
\end{abstract}

Mots clés: Carbone, azote, phosphore, soufre du sol, cycle du carbone, stockage du carbone, densité apparente, Luvisol gris, érosion du sol

The impact of management on soil organic matter has been researched extensively because organic matter is the primary reservoir of $\mathrm{N}, \mathrm{S}$ and other essential nutrients, and it interacts with mineral components to determine aggregation and other soil properties. More recently, soil organic matter has been recognized as an important source and sink in the global carbon cycle. Since soils contain about three times as much $\mathrm{C}$ as the atmosphere, the balance between inputs and outputs of $\mathrm{C}$ to the soil has a critical influence on the concentration of atmospheric $\mathrm{CO}_{2}$ and, possibly, global climate (Post et al. 1990).
Both biotic and geomorphic processes contribute to changes in organic $\mathrm{C}$ stored in soils under contrasting management regimes. Biotic processes dictate the balance between inputs of photosynthetically fixed $\mathrm{C}$ and outputs of $\mathrm{CO}_{2}$ from decomposition of soil organic matter. Management-induced changes in soil organic matter usually are attributed to differences in the amount, placement and composition of organic residues returned to the soil, and to changes in the environment (i.e. temperature, moisture, accessibility of energy sources) of the soil organisms. The influence of geomorphic processes on soil organic matter 


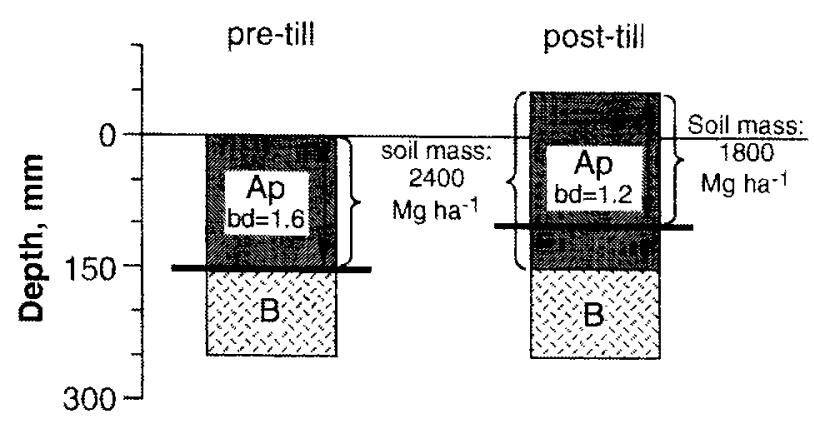

Figure 1. Tillage-induced changes in soil horizonation, bulk density and mass: tillage increases the thickness per unit area (i.e. volume) occupied by the same mass of soil and organic $\mathrm{C}$, thus misinterpretations are inevitable for calculations based on the fixed 0 to $150 \mathrm{~mm}$ layer (indicated by the double arrow) and quite likely for calculations based on identification of the boundary between the Ap and B horizons.

has received less attention. Soil erosion may not explain large losses of $\mathrm{C}$ on a regional scale (Schlesinger 1986), but has a major impact on redistribution of organic $\mathrm{C}$ within ecosystems (Slater and Carleton 1938; De Jong and Kachanoski 1988).

The impacts of management on soil organic matter are well documented, but the impacts of methods used to calculate amounts of organic matter stored in soils are equally important and inadequately documented. Various methods have been used to calculate the organic matter, C, N, P, S or carbonate status of soils. Amounts of organic matter or $\mathrm{C}$ were expressed simply as concentrations ( $\mathrm{kg} \mathrm{C} / \mathrm{Mg}$ soil) in most publications before 1970 (e.g. Alway and Trumbull 1910; Newton et al. 1945; Davidson et al. 1967). Although soil organic matter storage does increase with concentration, estimates in more recent publications account for the simple fact that storage of soil organic matter and nutrients per unit area or volume increase with concentration as well as soil bulk density and thickness.

Recognizing the dependence of organic matter storage on soil thickness and bulk density, most researchers now calculate soil organic matter and nutrient storage as the product of concentration, soil bulk density and soil thickness (e.g. Tiessen et al. 1982; Aguilar et al. 1988). This calculation method, although widely used, still is insufficient for assessing soil organic matter storage. As will be discussed, this method fails to account for the influence of soil mass on estimates of organic matter and nutrient storage.

Consider the amount of soil organic $\mathrm{C}$ in a soil before and after tillage without any gains or losses of soil or C (Fig. 1). The assumed concentration remains constant at $2 \%$ or $20 \mathrm{~kg}$ $\mathrm{C} \mathrm{Mg}^{-1}$ soil. Before tillage the soil has a bulk density of 1.6 $\mathrm{Mg} \mathrm{m}^{-3}$, such that the 0 to $150 \mathrm{~mm}$ layer consists of $2400 \mathrm{Mg}$ soil ha ${ }^{-1}$ and contains $48 \mathrm{Mg} \mathrm{C}^{-1}$. Then consider the impact of a single tillage operation that decreases soil bulk density to $1.2 \mathrm{Mg} \mathrm{m}^{-3}$ without changing the soil $\mathrm{C}$ concentration or causing lateral redistribution of the soil (Fig. 1). The 0 to $150 \mathrm{~mm}$ layer, which now begins $50 \mathrm{~mm}$ above the original surface, consists of $1800 \mathrm{Mg}$ soil ha $^{-1}$ and contains $36 \mathrm{Mg} \mathrm{C} \mathrm{ha}^{-1}$ or $25 \%$ less than present before tillage, despite the fact that organic matter has not been decomposed to $\mathrm{CO}_{2}$ or eroded from the field. The masses of soil and organic $\mathrm{C}$ in the genetic Ap horizon remained unchanged, but accurate identification of horizon boundaries in the field is difficult at best. Consequently, the impacts of management (a single tillage operation in this hypothetical instance) on soil organic $\mathrm{C}$ storage will be misinterpreted.

The objectives of this study are to examine various methods for calculating soil nutrient storage, and to assess how the mass of soil under consideration may influence the interpretation of comparative data. We discuss the influence of soil thickness and mass on estimates of organic C, N, P and $\mathrm{S}$ stored in native and cultivated Gray Luvisols at a site in central Saskatchewan. In addition, we reassess previously published data on management-induced changes in soil organic matter at several sites in North America and elsewhere.

\section{MATERIALS AND METHODS}

\section{Study site and soils}

The study site was situated near Star City, Saskatchewan $\left(52^{\circ} 48^{\prime} \mathrm{N}, 104^{\circ} 21^{\prime} \mathrm{W}\right)$, about $175 \mathrm{~km}$ northeast of Saskatoon. The soils were from the grassland-forest ecotone where cultivated farmland is interspersed with patches of trees. The soils are Orthic Gray Luvisols developed under forest vegetation on moderately calcareous, medium textured parent materials. The study site is nearly level (0.5-2.5\% slope), and soils were sampled from level areas where erosion appeared to be minor.

Seven soil profiles were sampled at the study site, including: two under native aspen forest (F1 and F2) which represent the soils prior to clearing for agriculture; one under a recently cleared plot $(\mathbf{R C})$ that had been plowed to loosen roots and rocks, and to mix the LFH layer and Ae horizon; one profile under long-term pasture (PA) that remained uncultivated since clearing; one under an alfalfa/oilseed rotation (AO) with alfalfa harvested as forage for 7 to $10 \mathrm{yr}$ periods; and two profiles under long-term wheat/fallow rotations (WF1 and WF2). The profiles differed with respect to vegetation, years of cultivation and frequency of summer fallow (Table 1).

Modal soil profiles were sampled by genetic horizon from pits excavated in June 1985. A volumetric sampler was used to measure bulk density of the organic layers and surface horizons surrounding the sampling pits. Subsequent sampling indicated that the influence of management on soil bulk density did not extend below $200 \mathrm{~mm}$, and that the mean bulk density of the subsurface horizons was approximately $1.5 \mathrm{Mg} \mathrm{m}^{-3}$.

Analyses for C, N, S and P were performed on finely ground subsamples $(<150 \mu \mathrm{m})$. Methods used to determine total and inorganic $\mathrm{C}, \mathrm{N}, \mathrm{S}, \mathrm{P}$, and sulfate-S are outlined in Roberts et al. (1989). Organic C, N, S, P, and sulfate-S were calculated as differences between the concentrations of total and inorganic elements.

\section{Calculations}

Element concentrations $\left(\mathrm{kg} \mathrm{Mg}^{-1}\right)$ were obtained directly from chemical analyses. Element masses in genetic horizons 


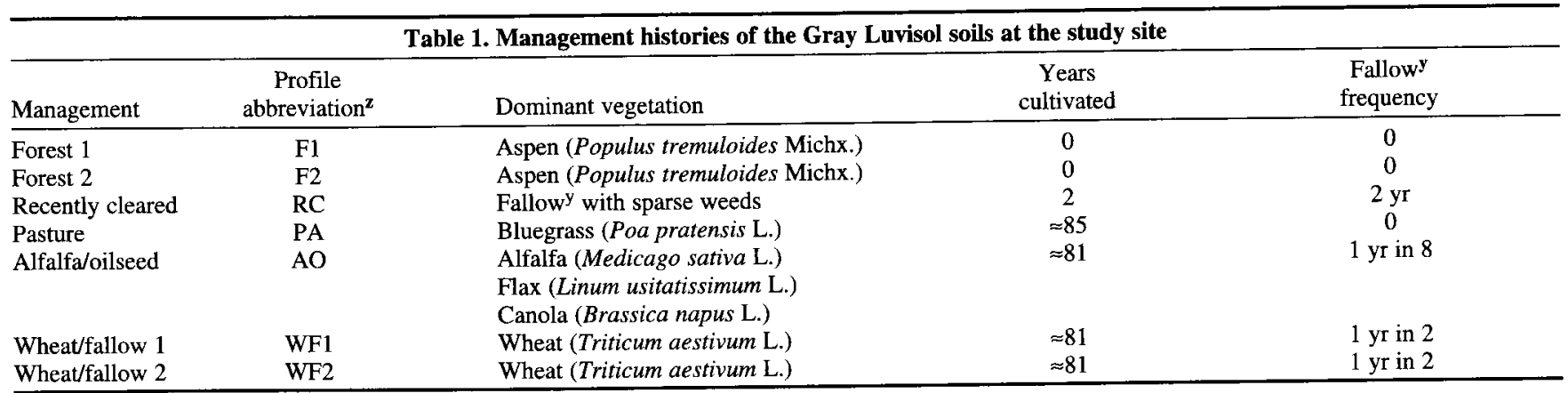

${ }^{\mathrm{z}}$ Horizon designations are appended to the profile abbreviations to identify specific soil layers, otherwise soils are from the surface horizons.

Fallow refers to tillage which prevents plant growth throughout an entire growing season.

$\left(\mathrm{Mg} \mathrm{ha}{ }^{-1}\right)$ were calculated from the thicknesses and bulk densities of the horizons:

$\mathrm{M}_{\text {element }}=\operatorname{conc} \cdot \rho_{\mathrm{b}} \cdot T \cdot 10000 \mathrm{~m}^{2} \mathrm{ha}^{-1} \cdot 0.001 \mathrm{Mg} \mathrm{kg}^{-1}(1)$

where:

$M_{\text {element }}=$ element mass per unit area $\left(\mathrm{Mg} \mathrm{ha}^{-1}\right)$

conc = element concentration $\left(\mathrm{kg} \mathrm{Mg}^{-1}\right)$

$\rho_{\mathrm{b}} \quad=$ field bulk density $\left(\mathrm{Mg} \mathrm{m}^{-3}\right)$

$T \quad=$ thickness of soil layer $(\mathrm{m})$

Area-based estimates of elements $\left(\mathrm{Mg} \mathrm{ha}^{-1}\right)$ generally have been regarded as the most appropriate means to describe standing stocks of elements in soils and other ecosystem pools (Schlesinger 1986; Davidson and Ackerman 1993), but few authors consider the relative mass of the soils being compared:

where:

$$
M_{\text {soil }}=\rho_{\mathrm{b}} \cdot T \cdot 10000 \mathrm{~m}^{2} \mathrm{ha}^{-1}
$$

$$
M_{\text {soil }}=\text { soil mass per unit area }\left(\mathrm{Mg} \mathrm{ha}^{-1}\right)
$$

Ideally, management-induced changes in organic matter can be assessed from comparisons among similar soils (i.e. identical original thickness, bulk density, texture) with contrasting management histories. Thus, management effects can be inferred simply from changes in element concentrations in the surface horizons, provided that changes in horizon thickness exactly compensate for changes in bulk density, such that soil masses are identical. In practice, however, management obliterates the genetic horizons, and alters the masses of the surface horizons (Fig. 2). At Star City the LFH layer, A horizon and top portion of the $\mathrm{B}$ horizon were mixed to form an Ap horizon.

To account for different soil masses, we calculated the amounts of $\mathrm{C}, \mathrm{N}, \mathrm{P}$ or $\mathrm{S}\left(\mathrm{Mg} \mathrm{ha}^{-1}\right)$ in an identical or "equivalent" mass of soil under contrasting management regimes. The mass of the heaviest soil layer which was most susceptible to the influence of management was designated as the "equivalent" mass. As will be discussed, the actual value selected as the equivalent mass was less important than the fact that the same standard or reference soil mass was used for comparisons of organic matter and nutrient storage at

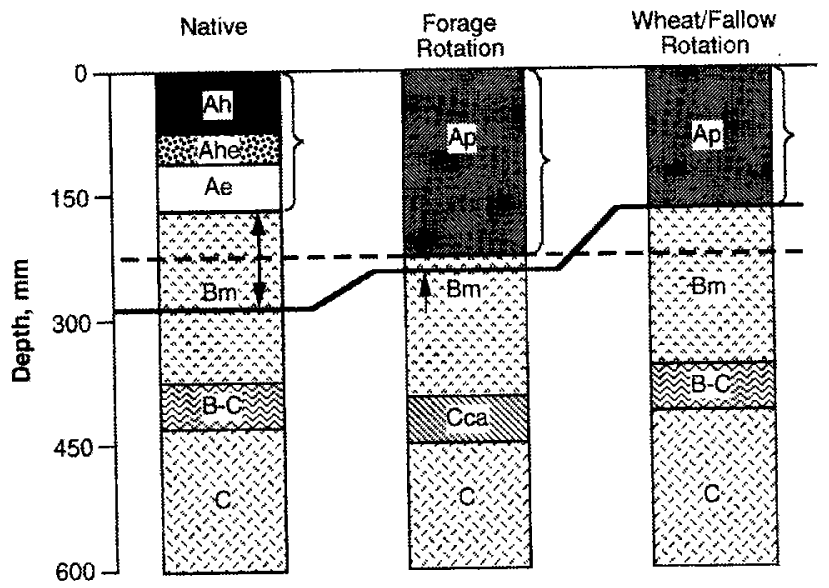

Figure 2. Schematic illustrations of methods to calculate the element status of soils under contrasting management regimes: brackets indicate layers for comparisons between genetic A horizons; the dashed line indicates layers compared for a fixed sampling depth; the solid line indicates layers compared for an equivalent mass of soil, and the arrows indicate the additional layer required to attain the equivalent soil mass.

each particular study site. The additional soil thickness required to attain this equivalent mass in lighter soil layers was calculated as follows:

$\mathrm{T}_{\text {add }}=\frac{\left(\mathrm{M}_{\text {soil, equiv }}-\mathrm{M}_{\text {soil, surf }}\right) \cdot 0.0001 \text { ha m}^{-2}}{\rho_{\mathrm{b} \text { subsurface }}}$

where:

$T_{\text {add }}=$ additional thickness of subsurface layer required to attain the equivalent soil mass $(\mathrm{m})$ $\begin{aligned} M_{\text {soil, equiv }}= & \text { equivalent soil mass = mass of heaviest hori- } \\ & \text { zon }\left(\mathrm{Mg} \mathrm{ha}^{-1}\right)\end{aligned}$

$M_{\text {soil, surf }}=$ sum of soil mass in surface layer(s) or genetic horizon(s) $\left(\mathrm{Mg} \mathrm{ha}^{-1}\right)$

$\rho_{\mathrm{b} \text { subsurface }}=$ bulk density of subsurface layer $\left(\mathrm{Mg} \mathrm{m}^{-3}\right)$

Masses of elements per unit area in an equivalent soil mass were calculated by summing the elements in surface layers or horizons, plus those in the additional thickness of subsurface layer required to attain the equivalent soil mass: 
Table 2. Element status of surface soils from Star City expressed as concentrations, masses per hectare in the genetic horizons, masses per hectare to a fixed depth, and masses per hectare in an equivalent mass of surface soil

\begin{tabular}{|c|c|c|c|c|c|c|c|c|c|}
\hline \multirow[b]{2}{*}{ Management } & \multirow{2}{*}{$\begin{array}{c}\text { Thickness } \\
(\mathrm{mm})\end{array}$} & \multirow{2}{*}{$\begin{array}{l}\text { Soil mass } \\
\left(\mathrm{Mg} \mathrm{ha}^{-1}\right)\end{array}$} & \multicolumn{4}{|c|}{ Organic forms of nutrients } & \multirow[b]{2}{*}{ Sulfate-S } & \multicolumn{2}{|c|}{ Total } \\
\hline & & & $\mathrm{C}$ & $\mathbf{N}$ & $\mathbf{P}$ & $S$ & & $\mathbf{P}$ & $S$ \\
\hline & & & \multicolumn{7}{|c|}{ Concentrations $\left(\mathrm{kg} \mathrm{Mg}^{-1}\right)$} \\
\hline Forest $1 \mathrm{LFH}$ & & & 181.6 & 10.35 & 0.62 & 1.00 & 0.240 & 1.01 & 1.02 \\
\hline Forest $1 \mathrm{Ae}$ & & & 11.1 & 0.92 & 0.11 & 0.09 & 0.033 & 0.56 & 0.09 \\
\hline Forest $2 \mathrm{LFH}$ & & & 281.1 & 13.61 & 0.78 & 1.34 & 0.343 & 1.18 & 1.37 \\
\hline Forest $2 \mathrm{Ae}$ & & & 5.1 & 0.44 & 0.07 & 0.05 & 0.016 & 0.54 & 0.05 \\
\hline Recently cleared & & & 31.0 & 1.76 & 0.14 & 0.20 & 0.055 & 0.60 & 0.21 \\
\hline Pasture & & & 22.4 & 1.80 & 0.23 & 0.20 & 0.083 & 0.58 & 0.21 \\
\hline Alfalfa/oilseed & & & 24.2 & 1.94 & 0.19 & 0.20 & 0.091 & 0.64 & 0.21 \\
\hline Wheat/fallow 1 & & & 22.2 & 1.84 & 0.22 & 0.19 & 0.079 & 0.62 & 0.20 \\
\hline Wheat/fallow 2 & & & 20.7 & 1.61 & 0.19 & 0.16 & 0.067 & 0.52 & 0.17 \\
\hline coeff. of variation & & & $146 \%$ & $124 \%$ & $86 \%$ & $120 \%$ & $103 \%$ & $34 \%$ & $119 \%$ \\
\hline
\end{tabular}

\begin{tabular}{|c|c|c|c|c|c|c|c|c|c|}
\hline & & \multicolumn{8}{|c|}{ Element masses in genetic horizons $\left(\mathrm{Mg} \mathrm{ha}^{-1}\right)$} \\
\hline Forest $1 \mathrm{LFH}+\mathrm{Ae}$ & 180 & 1199 & 45.9 & 2.91 & 0.23 & 0.28 & 0.08 & 0.76 & 0.29 \\
\hline Forest $2 \mathrm{LFH}+\mathrm{Ae}$ & 320 & 3155 & 58.1 & 3.39 & 0.32 & 0.35 & 0.10 & 1.79 & 0.37 \\
\hline Recently cleared & 150 & 1800 & 55.7 & 3.17 & 0.26 & 0.37 & 0.10 & 1.09 & 0.37 \\
\hline Pasture & 180 & 2340 & 52.4 & 4.22 & 0.53 & 0.48 & 0.19 & 1.36 & 0.49 \\
\hline Alfalfa/oilseed & 150 & 1800 & 43.5 & 3.50 & 0.34 & 0.37 & 0.16 & 1.15 & 0.37 \\
\hline Wheat/fallow 1 & 150 & 1920 & 42.7 & 3.53 & 0.43 & 0.36 & 0.15 & 1.20 & 0.38 \\
\hline Wheat/fallow 2 & 160 & 2208 & 45.7 & 3.56 & 0.42 & 0.36 & 0.15 & 1.15 & 0.38 \\
\hline coeff. of variation & & & $13 \%$ & $12 \%$ & $29 \%$ & $16 \%$ & $31 \%$ & $26 \%$ & $16 \%$ \\
\hline \multicolumn{10}{|c|}{ Element masses to a fixed depth $\left(M g h a^{-1}\right)$} \\
\hline Forest $1+$ LFH $^{\mathbf{z}}$ & 280 & 2699 & 54.1 & 3.80 & 0.43 & 0.38 & 0.13 & 1.32 & 0.40 \\
\hline Forest $2+\mathrm{LFH}^{\mathbf{z}}$ & 290 & 2726 & 55.9 & 3.20 & 0.30 & 0.33 & 0.09 & 1.56 & 0.34 \\
\hline Recently cleared & 180 & 2250 & 57.3 & 3.42 & 0.28 & 0.39 & 0.11 & 1.28 & 0.41 \\
\hline Pasture & 180 & 2340 & 52.4 & 4.22 & 0.53 & 0.48 & 0.19 & 1.36 & 0.49 \\
\hline Alfalfa/oilseed & 180 & 2250 & 45.7 & 3.73 & 0.39 & 0.40 & 0.18 & 1.33 & 0.40 \\
\hline Wheat/fallow 1 & 180 & 2370 & 44.7 & 3.76 & 0.48 & 0.39 & 0.16 & 1.37 & 0.41 \\
\hline Wheat/fallow 2 & 180 & 2508 & 46.9 & 3.78 & 0.45 & 0.38 & 0.16 & 1.26 & 0.41 \\
\hline coeff. of variation & & & $10 \%$ & $9 \%$ & $23 \%$ & $11 \%$ & $26 \%$ & $7 \%$ & $10 \%$ \\
\hline \multicolumn{10}{|c|}{ Element masses in equivalent soil mass ( $\left.\mathrm{Mg} \mathrm{ha^{-1 }}\right)$} \\
\hline Forest 1 & 256 & $2340^{y}$ & 52.1 & 3.59 & 0.38 & 0.36 & 0.12 & 1.19 & 0.37 \\
\hline Forest 2 & 263 & 2340 & 53.9 & 3.03 & 0.27 & 0.31 & 0.09 & 1.35 & 0.32 \\
\hline Recently cleared & 186 & 2340 & 57.6 & 3.47 & 0.29 & 0.40 & 0.11 & 1.32 & 0.42 \\
\hline Pasture & 180 & 2340 & 52.4 & 4.22 & 0.53 & 0.48 & 0.19 & 1.36 & 0.49 \\
\hline Alfalfa/oilseed & 186 & 2340 & 46.2 & 3.77 & 0.40 & 0.40 & 0.18 & 1.36 & 0.41 \\
\hline Wheat/fallow 1 & 178 & 2340 & 44.6 & 3.75 & 0.48 & 0.39 & 0.16 & 1.36 & 0.41 \\
\hline Wheat/fallow 2 & 169 & 2340 & 46.2 & 3.66 & 0.43 & 0.37 & 0.15 & 1.20 & 0.39 \\
\hline coeff. of variation & & & $9 \%$ & $10 \%$ & $24 \%$ & $13 \%$ & $28 \%$ & $6 \%$ & $12 \%$ \\
\hline
\end{tabular}

${ }^{2}$ The forest profiles include $180 \mathrm{~mm}$ of mineral soil plus the LFH layer.

yThe Ahe horizon of the Pasture profile was designated as the "equivalent soil mass" ( $\left.2340 \mathrm{Mg} \mathrm{ha}^{-1}\right)$, and the thickness of Bt horizon required to attain $2340 \mathrm{Mg} \mathrm{ha}{ }^{-1}$ in each of the other six profiles was used to calculate the quantity of element in the equivalent soil mass.

$$
M_{\text {element, equiv }}=M_{\text {element, surf }}+M_{\text {element, Tadd }}
$$

where:

$$
\begin{aligned}
M_{\text {element, equiv }}= & \text { element mass per unit area in an equiva- } \\
& \text { lent soil mass }\left(\mathrm{Mg} \mathrm{ha}^{-1}\right) \\
M_{\text {element, surf }=} & \text { sum of element mass in surface layer(s) } \\
& \left.\mathrm{Mg} \mathrm{ha}^{-1}\right) \\
M_{\text {element, Tadd }}= & \text { element mass in the additional subsurface } \\
& \text { layer }\left(\mathrm{Mg} \mathrm{ha}^{-1}\right)
\end{aligned}
$$

Amounts of soil organic C, N, S and P at the Star City site were expressed as concentrations $\left(\mathrm{kg} \mathrm{Mg}^{-1}\right)$, mass per unit area in genetic horizons $\left(\mathrm{Mg} \mathrm{ha}^{-1}\right)$, mass per unit area to a fixed depth of $180 \mathrm{~mm}$ (the depth of the original A horizon), and mass per unit area in an equivalent soil mass. The additional thickness required to attain $180 \mathrm{~mm}$ was obtained by subtraction, and element mass in the fixed depth increment was calculated as the sum of those in the surface layer(s) plus the additional thickness. Published data were re-analyzed to assess the merits of quantifying nutrient status as element masses in an equivalent soil mass.

\section{RESULTS AND DISCUSSION}

Concentrations and masses per unit area of $\mathrm{C}, \mathrm{N}, \mathrm{P}$ and $\mathrm{S}$ in the surface soils varied widely among contrasting profiles (Table 2). The surface layers were most relevant to assess the impact of management on nutrient status, because surface soils were modified directly by cultivation. Concentrations in the LFH layers were much greater than those in the mineral 
Table 3. Effect of method used to express nutrient status on comparisons between the native and cultivated soils investigated by Tiessen and coworkers (1982)

\begin{tabular}{|c|c|c|c|c|c|c|c|}
\hline \multirow{2}{*}{$\begin{array}{l}\text { Management, years } \\
\text { of cultivation }\end{array}$} & \multirow{2}{*}{$\begin{array}{l}\text { Thickness } \\
\text { (mm) }\end{array}$} & \multirow{2}{*}{$\begin{array}{c}\text { Bulk density } \\
\left(\mathrm{Mg} \mathrm{m}^{-3}\right)\end{array}$} & \multirow{2}{*}{$\begin{array}{l}\text { Soil mass } \\
\left(\mathrm{Mg} \mathrm{ha}^{-1}\right)\end{array}$} & \multicolumn{2}{|c|}{ Organic $\mathrm{C}$} & \multicolumn{2}{|c|}{ Total N } \\
\hline & & & & Content & Decrease $^{\mathbf{y}}$ & Content & Decrease \\
\hline & & & & \multicolumn{4}{|c|}{ Concentration $\left(\mathrm{kg} \mathrm{Mg}^{-1}\right)$} \\
\hline Blaine Lake Native & & & & 47.9 & & 4.42 & \\
\hline Blaine Lake 4 yr & & & & 49.0 & -1.1 & 4.39 & 0.03 \\
\hline Blaine Lake $60 \mathrm{yr}$ & & & & 32.8 & 15.1 & 2.91 & 1.51 \\
\hline Blaine Lake $90 \mathrm{yr}$ & & & & 20.0 & 27.9 & 2.18 & 2.24 \\
\hline Sutherland Native & & & & 37.7 & & 3.04 & \\
\hline Sutherland $70 \mathrm{yr}$ & & & & 23.7 & 14.0 & 2.50 & 0.54 \\
\hline Bradwell Native & & & & 32.2 & & 3.28 & \\
\hline \multirow[t]{2}{*}{ Bradwell 65 yr } & & & & 17.4 & 14.8 & 1.76 & 1.52 \\
\hline & & & & \multicolumn{4}{|c|}{ Genetic A Horizon $\left(M g h a^{-1}\right)$} \\
\hline Blaine Lake Native & 108 & 1.04 & 1123 & 53.8 & & 4.96 & \\
\hline Blaine Lake 4 yr & 133 & 1.04 & 1383 & 67.8 & -14.0 & 6.07 & -1.11 \\
\hline Blaine Lake 60 yr & 145 & 1.22 & 1769 & 58.0 & -4.2 & 5.15 & -0.19 \\
\hline Blaine Lake 90 yr & 90 & 1.30 & 1170 & 23.4 & 30.4 & 2.55 & 2.41 \\
\hline Sutherland Native & 180 & 0.98 & 1764 & 66.5 & & 5.36 & \\
\hline Sutherland $70 \mathrm{yr}$ & 180 & 1.28 & 2304 & 54.6 & 11.9 & 5.76 & 0.40 \\
\hline Bradwell Native & 148 & 1.07 & 1584 & 51.0 & & 5.19 & \\
\hline \multirow[t]{2}{*}{ Bradwell 65 yr } & 138 & 1.45 & 2001 & 34.8 & 16.2 & 3.52 & 1.67 \\
\hline & & & & \multicolumn{4}{|c|}{ Equivalent mass $\left(M g h a^{-1}\right)$} \\
\hline Blaine Lake Native & 157 & & $1769^{x}$ & 63.8 & & 6.03 & \\
\hline Blaine Lake 4 yr & 161 & & 1769 & 74.8 & -11.0 & 6.76 & -0.73 \\
\hline Blaine Lake $60 \mathrm{yr}$ & 145 & & 1769 & 58.0 & 5.8 & 5.15 & 0.88 \\
\hline Blaine Lake $90 \mathrm{yr}$ & 133 & & 1769 & 30.2 & 33.6 & 3.23 & 2.80 \\
\hline Sutherland Native & 225 & & $2304^{w}$ & 78.7 & & 6.63 & \\
\hline Sutherland $70 \mathrm{yr}$ & 180 & & 2304 & 54.6 & 24.1 & 5.76 & 0.87 \\
\hline Bradwell Native & 200 & & 2304 & 60.1 & & 6.12 & \\
\hline Bradwell $65 \mathrm{yr}$ & 159 & & 2304 & 38.1 & 22.0 & 3.86 & 2.26 \\
\hline
\end{tabular}

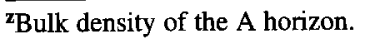

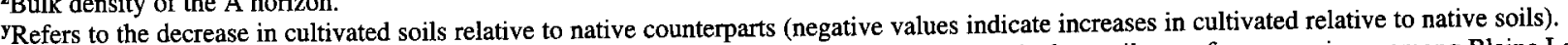

The A horizon which had been cultivated for $60 \mathrm{yr}$ (greatest mass) was designated as the equivalent soil mass for comparisons among Blaine Lake soils.

whe cultivated A horizon of the Sutherland profile was designated as the equivalent soil mass for comparisons among Sutherland and Bradwell soils.

soils, and were smallest in the leached Ae horizons. Concentrations indicated element distribution within the profiles, but estimation of element mass per unit area required consideration of the physical dimensions of individual horizons in the profiles.

\section{Element Masses ( $\mathrm{Mg} \mathrm{ha}^{-1}$ ) in Genetic Horizons}

Thicknesses of genetic horizons are dictated by profile morphology. Sampling by genetic horizon is justified when differences in profile morphology coincide with sharp changes in element concentration within the profile. At the Star City site, concentrations changed sharply with depth in profiles under native vegetation and in cultivated profiles with distinct Ap horizons. Element masses in the forest LFH and Ae horizons were summed because the two layers were combined in the other profiles (Table 2). Variability among element masses in surface soils of contrasting profiles was far less than variability among element concentrations, because low bulk densities compensated for high concentrations in the LFH layers.

Masses of soil in genetic horizons at the surface of the profiles varied according to the horizon thicknesses and bulk densities, and ranged from 1199 to $3155 \mathrm{Mg} \mathrm{ha}^{-1}$ (Table 2). Despite the small forest litter masses (150-190 $\mathrm{Mg} \mathrm{ha}^{-1}$ ), the LFH layers contained considerable masses of organic $\mathrm{C}, \mathrm{N}, \mathrm{S}$ and $\mathrm{P}$. Differences among the masses of genetic horizons obscured the influence of cultivation on masses of elements per unit area. The dependence of the element masses on the soil mass was especially evident for total P

(total $\mathrm{P}=0+0.00058 \cdot$ soil mass, $R^{2}=0.996, P<0.0001$ ), indicating that variability in total $P$ was attributable to differences in soil mass rather than management.

\section{Element Masses $\left(\mathrm{Mg} \mathrm{ha}^{-1}\right)$ in a Fixed Sampling Depth}

Element masses were calculated for the 0 to $180 \mathrm{~mm}$ thickness of mineral soils at the surface of the profiles (Table 2). The 0 - to $180-\mathrm{mm}$ thickness included the layers most influenced by management. Elements in the forest LFH layers were added to those in the surface $180 \mathrm{~mm}$ of mineral soil, because the litter had been mixed into the mineral soil at the surfaces of the other profiles. The soil masses contained in the fixed sampling depth were uniform (cv. $=8 \%$, compared with $29 \%$ for masses of the genetic horizons), because the forest soil masses included $180 \mathrm{~mm}$ of mineral soil and the other surface soils had similar bulk densities $(1.20-1.38 \mathrm{Mg}$ $\mathrm{m}^{-3}$ ). Since the soil masses were uniform, element masses in the fixed depth were less variable than those contained in the genetic horizons (Table 2). 


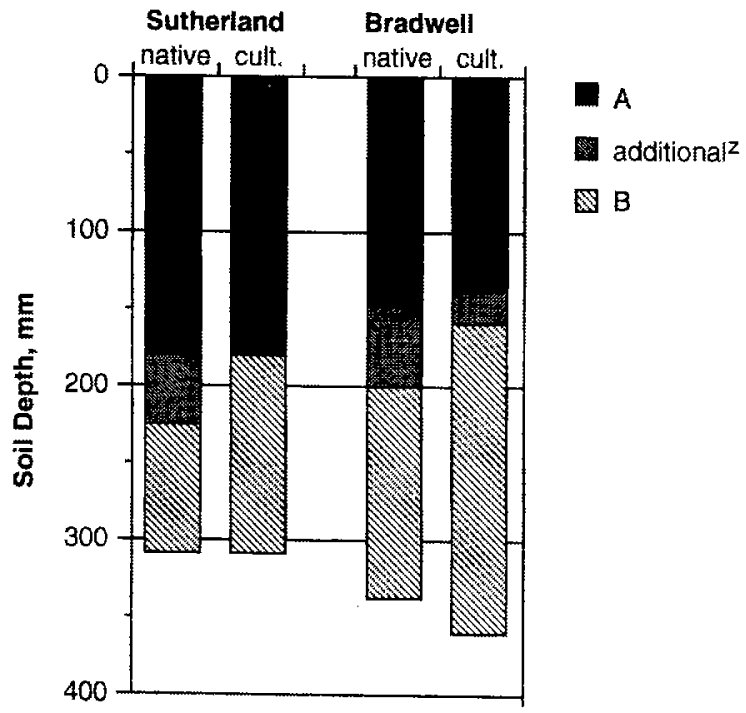

Figure 3. Thicknesses of genetic horizons and of layers required to attain the equivalent soil mass in native and cultivated profiles of the Sutherland and Bradwell soils studied by Tiessen et al. (1982). $\mathrm{Z}_{\text {additional }}=$ layer of $\mathrm{B}$ horizon required to attain the equivalent soil mass.

\section{Element Masses $\left(\mathrm{Mg} \mathrm{ha}^{-1}\right)$ in an Equivalent Soil Mass}

The mass of the surface horizon of the PA profile $(2340 \mathrm{Mg}$ $\mathrm{ha}^{-1}$ ) was designated the equivalent soil mass (Table 2). The surface layers ( $\mathrm{LFH}+\mathrm{Ae}$ ) of the $\mathrm{F} 2$ profile had the greatest soil mass and thickness, but the mass and thickness of the surface layer of the PA profile were more representative of the other profiles. Selection of the equivalent soil mass, like selection of the fixed sampling depth, is somewhat arbitrary, but it must be identical for all profiles being compared and include the soil layer most susceptible to the influence of management. Differences in horizonation among study sites may justify the use of unique soil masses for each study, but evaluation of management impacts requires that soils at each site originally were comparable.

Element masses in the equivalent mass of surface soil were less variable than those in the genetic horizons, because variability caused by unequal soil masses was eliminated. The remaining variability among element masses originated from management impacts and unmeasured sources of error. The coefficients of variation for total $P$ in the contrasting profiles were $34 \%$ for concentration, $26 \%$ for mass in genetic horizons, $7 \%$ for mass in the fixed depth, and $6 \%$ for mass in the equivalent soil mass (Table 2). The greater variability among the masses of organic C, N, P, S and sulfate in the equivalent soil mass indicated that management had a greater impact on elements in the organic fraction than on total P.

The mass of organic $\mathrm{C}$ in the soil thickness required to attain $2340 \mathrm{Mg}$ soil ha $^{-1}$ was less in the cultivated soils (46 $\pm 0.9 \mathrm{Mg} \mathrm{C} \mathrm{ha}^{-1}$ in WF1, WF2, AO soils) than in soils that were not subjected to annual tillage $\left(54 \pm 2.5 \mathrm{Mg} \mathrm{Cha}^{-1}\right.$ in F1, F2, RC, and PA soils) (Table 2). The loss of organic C from the equivalent soil mass after $\approx 80 \mathrm{yr}$ of cultivation was $8 \mathrm{Mg} \mathrm{ha}^{-1}$ or about $15 \%$ of the $\mathrm{C}$ originally present. The mass of organic sulfate- $S$ increased from an average of $0.10 \mathrm{Mg} \mathrm{ha}^{-1}$ in the F1, F2 and $\mathrm{RC}$ soils to $0.17 \mathrm{Mg} \mathrm{ha}^{-1}$ in the agricultural soils (PA, AO, WF1, WF2). Relationships between cultivation and masses of organic $\mathrm{N}, \mathrm{S}$ and $\mathrm{P}$ in contrasting soils were unclear, but the PA soil accumulated the greatest nutrient masses (Table 2).

Nutrient storage was also calculated for the equivalent mass of subsoil ( $2340 \mathrm{Mg}$ soil ha ${ }^{-1}$ ) immediately below the equivalent mass of surface soil (data not shown). The amounts of $\mathrm{C}$ and $\mathrm{N}$ stored in the subsurface equivalent mass were about $20 \%$ of those stored in the surface equivalent soil mass, but differences associated with management were not apparent.

\section{Reassessment of Previously Published Data}

Reassessment of management-induced changes in soil organic matter indicated that comparisons among unequal soil masses influenced estimates of nutrient depletion. In the Chernozemic soils studied by Tiessen et al. (1982) cultivation increased bulk densities and soil masses of the genetic (Ap) horizons. Estimates of $\mathrm{C}$ and $\mathrm{N}$ depletion, therefore, were greater for comparisons between elements in an equivalent soil mass than those in genetic horizons (Table 3 ). The Ap horizon of the Blaine Lake soil which had been cultivated for $60 \mathrm{yr}$ gained about $4 \mathrm{Mg} \mathrm{C}^{-1}$, but $6 \mathrm{Mg} \mathrm{C}$ $\mathrm{ha}^{-1}$ was lost from the equivalent soil mass. Discrepancies between element depletion in genetic horizons and equivalent masses were especially obvious in the Sutherland and Bradwell soils. Since cultivation mixed some $B$ horizon into the Ap, element masses in the portions of B horizon needed to attain equivalent soil mass were added to element masses in the A horizons of native profiles (Fig. 3).

Reassessment of data from several studies of management-induced decreases in soil organic $\mathrm{C}$ and $\mathrm{N}$ indicated that the decreases usually were greater when comparisons were between equivalent soil masses rather than genetic horizons or fixed sampling depths (Tables 4 and 5). Uncultivated soils tended to have lower bulk densities so that thicker soil layers were required to attain the equivalent soil mass in uncultivated compared to cultivated soils. Differences between element depletion in the equivalent mass and genetic horizons were large when the genetic horizons under consideration had different thicknesses (e.g. grassland soils in South Dakota and Missouri, Table 5). When soils under contrasting management had similar thicknesses and bulk densities, the decreases in $\mathrm{C}$ were similar regardless of the method used to calculate soil C (e.g. sandy loam in Ontario, Table 5).

Estimates of $\mathrm{C}$ and $\mathrm{N}$ stored in the surfaces of no-till and plowed soils also were influenced by the method used to calculate element status (Table 6). Doran (1987) reported that the surfaces of no-till soils contained more $\mathrm{C}$ and $\mathrm{N}$ than plowed soils. Reassessment of the data showed that the plowed soils (except for wheat on soil D in NB) had slightly lower bulk densities so that a greater thickness was required to attain the equivalent soil mass. Consequently the differences between $\mathrm{C}$ and $\mathrm{N}$ stored in no-till and plowed 
Table 4. Influence of methods to express soil carbon and nitrogen on the interpretation of management-induced changes in soil organic matter

\begin{tabular}{|c|c|c|c|c|c|c|c|c|c|c|}
\hline \multirow[b]{2}{*}{ Management } & \multicolumn{6}{|c|}{$\mathrm{C} \& \mathrm{~N}$ in sampled depth } & \multicolumn{4}{|c|}{$\mathrm{C} \& \mathrm{~N}$ in an equivalent soil mass } \\
\hline & \multicolumn{2}{|c|}{ Concentrations } & $\begin{array}{c}\text { Thickness } \\
\text { (mm) }\end{array}$ & $\begin{array}{l}\text { Soil Mass } \\
\left(\mathrm{Mg} \mathrm{ha}^{-1}\right)\end{array}$ & $\begin{array}{c}\text { C Mass } \\
\left(\mathrm{Mg} \mathrm{ha}^{-1}\right)\end{array}$ & $\begin{array}{c}\text { N Mass } \\
\left(\mathrm{Mg} \mathrm{ha}^{-1}\right) \\
\end{array}$ & $\begin{array}{c}\text { Thickness } \\
\text { (mm) }\end{array}$ & $\begin{array}{l}\text { Soil Mass } \\
\left(\mathrm{Mg} \mathrm{ha}^{-1}\right)\end{array}$ & $\begin{array}{c}\text { C Mass } \\
\left(\mathrm{Mg} \mathrm{ha}^{-1}\right)\end{array}$ & $\begin{array}{l}\text { N Mass } \\
\left(\mathrm{Mg} \mathrm{ha}^{-1}\right)\end{array}$ \\
\hline \multicolumn{11}{|c|}{ Grassland soils (Rendzina), Texas (Laws and Evans, 1949) } \\
\hline Virgin IA & 30.2 & 2.70 & 152 & 1583 & 47.8 & 4.27 & 190 & 2011 & 56.2 & 4.92 \\
\hline Cultivated IA & 16.2 & 1.60 & 152 & 1466 & 23.8 & 2.35 & 201 & 2011 & 30.8 & 3.22 \\
\hline Decrease & 13.9 & 1.10 & & & 23.9 & 1.93 & & & 25.4 & 1.70 \\
\hline Virgin IB & 32.5 & 1.60 & 152 & 1684 & 54.7 & 2.69 & 181 & 2011 & 62.7 & 3.15 \\
\hline Cultivated IB & 16.8 & 1.60 & 152 & 2011 & 33.8 & 3.22 & 152 & 2011 & 33.8 & 3.22 \\
\hline Decrease & 15.7 & 0.00 & & & 20.9 & -0.52 & & & 28.8 & -0.07 \\
\hline \multicolumn{11}{|c|}{ Podzols and Gleysols, Quebec (Martel et Deschenes, 1976) } \\
\hline Virgin Kamouraska Ah-Aeg & 67.0 & 2.80 & 170 & 2380 & 159.5 & 6.66 & 188 & 2720 & 160.9 & 6.85 \\
\hline Cultivated Kamouraska Ap & 37.0 & 2.30 & 170 & 2720 & 100.6 & 6.26 & 170 & 2720 & 100.6 & 6.26 \\
\hline Decrease & 30.0 & 0.50 & & & 58.8 & 0.41 & & & 60.2 & 0.59 \\
\hline Virgin, Charlevoix L-H+Ae-B & & & 190 & 1608 & 99.0 & 4.90 & 283 & 2720 & 114.6 & 5.01 \\
\hline Cultivated Charlevoix Ap & 37.0 & 2.20 & 150 & 1410 & 52.2 & 3.10 & 259 & 2720 & 74.4 & 4.23 \\
\hline Decrease & & & & & 46.9 & 1.79 & & & 40.2 & 0.78 \\
\hline Virgin Greensboro Ah-Ae & 103.0 & 7.80 & 70 & 420 & 43.3 & 3.28 & 262 & 2720 & 82.4 & 6.96 \\
\hline Cultivated Greensboro Ap & 24.0 & 2.00 & 170 & 2040 & 49.0 & 4.08 & 222 & 2720 & 53.3 & 4.66 \\
\hline Decrease & 79.0 & 5.80 & & & -5.7 & -0.80 & & & 29.0 & 2.29 \\
\hline
\end{tabular}

${ }^{\mathbf{z}}$ Bulk density was estimated from total porosity estimated by pressure pycnometer and an assumed particle density of $2.65 \mathrm{Mg} \mathrm{m}{ }^{-3}$; [Organic C] was calculated from [Organic Matter]/1.724.

${ }^{y_{C}}$ and $\mathrm{N}$ concentrations are reported separately for the L-H and AeBfl layers in Martel and Deschenes (1976).

\begin{tabular}{|c|c|c|c|c|c|c|}
\hline \multirow[b]{2}{*}{ Management } & \multicolumn{3}{|c|}{ C in sampled depth } & \multicolumn{3}{|c|}{$\mathrm{C}$ in equivalent soil mass } \\
\hline & $\begin{array}{l}\text { Thickness } \\
\text { (mm) }\end{array}$ & $\begin{array}{l}\text { Soil mass } \\
\left(\mathrm{Mg} \mathrm{ha}^{-1}\right)\end{array}$ & $\begin{array}{c}\text { C mass } \\
\left(\mathrm{Mg} \mathrm{ha}^{-1}\right)\end{array}$ & $\begin{array}{l}\text { Thickness } \\
(\mathrm{mm})\end{array}$ & $\begin{array}{l}\text { Soil mass } \\
\left(\mathrm{Mg} \mathrm{ha}^{-1}\right)\end{array}$ & $\begin{array}{c}\mathrm{C} \text { mass } \\
\left(\mathrm{Mg} \mathrm{ha}^{-1}\right)\end{array}$ \\
\hline \multicolumn{7}{|c|}{ Grassland soils (Borolls), South Dakota (Blank and Fosberg 1989) } \\
\hline Virgin & 150 & 1995 & 69.8 & 202 & 2826 & 78.1 \\
\hline Cultivated & 180 & 2826 & 73.5 & 180 & 2826 & 73.5 \\
\hline Decrease & & & -3.7 & & & 4.7 \\
\hline \multicolumn{7}{|c|}{ Tallgrass Prairie soils (Borolls), Missouri (Buyanovsky et al. 1987)y } \\
\hline Prairie & 250 & 3095 & 72.3 & 299 & 3790 & 80.8 \\
\hline Winter Wheat & 280 & 3790 & 54.2 & 280 & 3790 & 54.2 \\
\hline Decrease & & & 18.2 & & & 26.7 \\
\hline \multicolumn{7}{|c|}{ Tallgrass Prairie soils (Udolls), Oklahoma (Davidson et al. 1967) $\mathrm{y}$} \\
\hline Perennial Forage & 203 & 3022 & 28.3 & 216 & 3220 & 30.0 \\
\hline Continuous Cotton & 203 & 3220 & 20.2 & 203 & 3220 & 20.2 \\
\hline Decrease & & & 8.1 & & & 9.8 \\
\hline \multicolumn{7}{|c|}{ Grassland soils (Borolls), Nebraska (Doran 1987) } \\
\hline Native Sod & 150 & 1755 & 33.8 & 167 & 2070 & 36.7 \\
\hline SubTilled Wheat & 150 & 2070 & 30.4 & 150 & 2070 & 30.4 \\
\hline Decrease & & & 3.4 & & & 6.3 \\
\hline \multicolumn{7}{|c|}{ Brunisols and Gleysols, Ontario(Coote and Ramsey 1983) } \\
\hline Untilled sandy loam & 200 & 2630 & 64.5 & 229 & 3040 & 69.5 \\
\hline Tilled sandy loam & 200 & 2790 & 71.0 & 217 & 3040 & 75.8 \\
\hline Decrease & & & -6.5 & & & -6.3 \\
\hline Untilled loamy sand & 200 & 2630 & 56.9 & 232 & 3040 & 62.6 \\
\hline Tilled loamy sand & 200 & 2940 & 55.6 & 206 & 3040 & 56.5 \\
\hline Decrease & & & 1.3 & & & 6.1 \\
\hline Untilled clay & 200 & 1920 & 166.0 & 319 & 3040 & 259.8 \\
\hline Tilled clay & 200 & 2240 & 145.7 & 268 & 3040 & 187.5 \\
\hline Decrease & & & 20.3 & & & 72.3 \\
\hline Untilled clay loam & 200 & 2680 & 56.1 & 230 & 3040 & 58.7 \\
\hline Tilled clay loam & 200 & 3040 & 44.8 & 200 & 3040 & 44.8 \\
\hline Decrease & & & 11.3 & & & 13.8 \\
\hline \multicolumn{7}{|c|}{ Alfisols, Nigeria (Aina 1979) } \\
\hline Iwo Grass Pasture & 140 & 1806 & 39.1 & 165 & 2184 & 42.5 \\
\hline Iwo Cropped \& Fertilized & 140 & 2184 & 9.4 & 140 & 2184 & 9.4 \\
\hline Decrease & & & 29.7 & & & 33.1 \\
\hline Oba Bush & 140 & 1610 & 25.9 & 178 & 2184 & 29.1 \\
\hline Oba Cropped \& Plowed & 140 & 2072 & 7.6 & 147 & 21184 & 7.7 \\
\hline Decrease & & & 18.3 & & & 21.4 \\
\hline
\end{tabular}

${ }^{\mathrm{z} H o r i z o n}$ thickness are for the Williams site (site 1); other data are averages for all six sites.

y [Organic C] calculated from [Organic Matter]/1.724.

$\mathrm{x}_{51}$ to $127 \mathrm{~mm}$ layer assumed to represent 9 to $127 \mathrm{~mm}$ layer 
Table 6. Influence of methods to express soil carbon and nitrogen on comparisons between the no-till and plowed soils investigated by Doran (1987)

\begin{tabular}{|c|c|c|c|c|c|c|c|c|}
\hline \multirow[b]{2}{*}{ Management } & \multicolumn{4}{|c|}{ C \& $\mathrm{N}$ in sampled depth } & \multicolumn{4}{|c|}{$\mathrm{C} \& \mathrm{~N}$ in equivalent soil mass } \\
\hline & $\begin{array}{c}\text { Thickness } \\
(\mathrm{mm})\end{array}$ & $\begin{array}{l}\text { Soil mass } \\
\left(\mathrm{Mg} \mathrm{ha}^{-1}\right)\end{array}$ & $\begin{array}{c}C \text { mass } \\
\left(\mathrm{Mg} \mathrm{ha}^{-1}\right)\end{array}$ & $\begin{array}{c}\mathrm{N} \text { mass } \\
\left(\mathrm{Mg} \mathrm{ha}^{-1}\right)\end{array}$ & $\begin{array}{c}\text { Thickness } \\
(\mathrm{mm})\end{array}$ & $\begin{array}{l}\text { Soil mass } \\
\left(\mathrm{Mg} \mathrm{ha}^{-1}\right)\end{array}$ & $\begin{array}{c}\mathrm{C} \text { mass } \\
\left(\mathrm{Mg} \mathrm{ha}^{-1}\right)\end{array}$ & $\begin{array}{c}\mathrm{N} \text { mass } \\
\left(\mathrm{Mg} \mathrm{ha}^{-1}\right)\end{array}$ \\
\hline \multicolumn{9}{|l|}{ Surface Layers } \\
\hline No-till maize, KY & 75 & 945 & 21.2 & 2.17 & 84 & 1073 & 22.6 & 2.35 \\
\hline Plowed maize, KY & 75 & 893 & 12.1 & 1.49 & 88 & 1073 & 14.2 & 1.75 \\
\hline Decrease & & & 9.1 & 0.68 & & & 8.4 & 0.60 \\
\hline No-till maize, IL & 75 & 1065 & 13.8 & 1.28 & 76 & 1073 & 13.9 & 1.28 \\
\hline Plowed maize, $\Pi \mathrm{L}$ & 75 & 975 & 9.2 & 1.10 & 82 & 1073 & 10.1 & 1.20 \\
\hline Decrease & & & 4.6 & 0.17 & & & 3.7 & 0.08 \\
\hline No-till maize, $\mathrm{MN}$ & 75 & 975 & 29.4 & 2.60 & 83 & 1073 & 32.3 & 2.86 \\
\hline Plowed maize, $\mathrm{MN}$ & 75 & 878 & 26.3 & 2.39 & 91 & 1073 & 32.6 & 2.96 \\
\hline Decrease & & & 3.2 & 2.20 & & & -0.3 & -0.10 \\
\hline No-till maize, NB & 75 & 1073 & 18.8 & 1.73 & 75 & 1073 & 18.8 & 1.73 \\
\hline Plowed maize, NB & 75 & 915 & 13.0 & 1.19 & 87 & 1073 & 15.3 & 1.41 \\
\hline Decrease & & & 5.9 & 0.55 & & & 3.5 & 0.32 \\
\hline No-till wheat $A, N B$ & 75 & 968 & 11.5 & 1.17 & 83 & 1073 & 12.5 & 1.29 \\
\hline Plowed wheat A, NB & 75 & 938 & 9.1 & 0.90 & 85 & 1073 & 10.3 & 1.04 \\
\hline Decrease & & & 2.4 & 0.27 & & & 2.2 & 0.25 \\
\hline No-till wheat D, NB & 75 & 803 & 18.6 & 1.75 & 95 & 1073 & 22.0 & 2.10 \\
\hline Plowed wheat D, NB & 75 & 915 & 13.2 & 1.40 & 87 & 1073 & 15.4 & 1.63 \\
\hline Decrease & & & 5.4 & 0.35 & & & 6.6 & 0.47 \\
\hline
\end{tabular}

soils were smaller when an equivalent soil mass was considered. Comparisons between no-till and plowed soils in England indicated no significant differences in soil $\mathrm{C}$ and $\mathrm{N}$ when differences in soil mass were considered (Powlson and Jenkinson 1981).

\section{Validity of Comparisons among Elements in an Equivalent Soil Mass}

Comparisons between native and cultivated profiles or among soils under dissimilar management regimes traditionally have been used to evaluate losses or gains of nutrients associated with cultivation and management (e.g. Lawes and Gilbert 1885; Alway and Trumbull 1910; Newton et al. 1945). The actual comparisons deviated considerably from ideal experiments in which treatments were uniformly imposed on identical soils. Spatial variability among adjacent soils introduced noise to the data, changes in bulk densities rarely compensated for changes in horizon thicknesses, and management altered the masses of the soils being compared (Fig. 2).

Variability among masses of genetic horizons and sola originate from landscape variability and sampling errors, from vertical redistribution by truncation of subsurface horizons or compaction of surface layers, and from lateral redistribution by soil erosion or deposition. Tillage often increases the masses of Ap horizons relative to uncultivated A horizons, because soil from subsurface horizons is mixed into the overlying Ap (Aguilar et al. 1988). To account for soil redistribution, some authors suggested that comparisons be made among organic $C$ in entire sola (Voroney et al. 1981). Sola comparisons, however, obscure management effects that are most pronounced at the surface, and are unreliable indicators of soil redistribution. Recently Davidson and Ackerman (1993) recommended that assessments of soil C be based on genetic horizons rather than fixed depths, but their comparisons of $\mathrm{C}$ inventories in cultivated and uncultivated plots were influenced by differences in soil mass.
Comparisons among elements stored in an equivalent soil mass correct for changes in soil mass at sites that are influenced by vertical redistribution or landscape variability (Table 3). Sites with changes in soil mass that are caused by lateral redistribution require estimation of soil erosion and deposition before reliable comparisons of element masses can be made. Explicit assumptions about soil redistribution may justify comparisons among unequal soil masses, but indiscriminate comparisons among unequal soil masses have caused misinterpretations (Tables 4, 5 and 6). Simple comparisons among element masses in horizons or sola of contrasting soils provide only crude estimates of element depletion or accumulation and fail to distinguish between changes caused by geomorphic (erosion, deposition) and biotic (decomposition, photosynthesis) processes. Independent estimates of soil movement (e.g. ${ }^{137}$ Cesium redistribution) are required to estimate nutrient losses in eroded landscapes (Gregorich and Anderson 1985).

Calculations of element masses in an equivalent soil mass are based on assumed element concentrations and bulk densities. The element concentrations and bulk densities of the entire subsurface horizons were assumed to represent those in the top portions of the horizon required to attain the equivalent soil mass. Concentrations in the portions of $\mathrm{B}$ horizon (immediately below the A horizons) likely exceeded the average concentrations for the entire B horizons, but such discrepancies would cause conservative increases in the element masses of light soils relative to heavy soils (i.e. soils near the equivalent mass). Detailed sampling at small depth increments will diminish errors caused by discrepancies between element concentrations in entire horizons and portions thereof.

Previous workers have used similar methods to compensate for the confounding influence of management on the masses of soil in genetic horizons or fixed depths. Nye and Greenland (1964) recognized that comparisons of soil 
organic matter " ... should be based on the same soil mass, or the possible error involved in sampling to a fixed depth clearly recognized." Elaborate methods to account for changes in soil volume and for the mass of organic matter accumulated in the soil also have been considered (Henzell et al. 1967). The method we used to calculate element masses in an equivalent soil mass neglects small contributions of additional organic matter to soil mass, and is similar to the method used by workers at the Rothamsted Experimental Station (Jenkinson and Johnston 1976). These workers blended surface and subsurface soils to obtain samples that represented the same soil mass per hectare, and called their method "equivalent depth sampling" (Ayanaba et al. 1976; Powlson and Jenkinson 1981).

\section{CONCLUSIONS}

Assessments of management-induced changes in the quantities of $\mathrm{C}$ and other elements stored in soils were influenced by the method used to calculate element status. Comparisons among element concentrations were unreliable, because concentrations did not adequately reflect element masses per unit area or volume. Conventional estimates of element masses in genetic horizons or fixed sampling depths (calculated as the product of concentration, bulk density and thickness) usually resulted in comparisons among unequal soil masses. Such comparisons usually were unjustified, because soil sampling and identification of horizonation in the field were unreliable indicators of soil redistribution.

If soil redistribution was accurately indicated by field sampling procedures, the masses of cultivated soils should have been equal to or, if erosion had occurred, less than those of adjacent soils that had never been cultivated. Published data indicated the opposite: topsoil masses generally were greater for cultivated profiles than for profiles under native vegetation, because cultivation changed soil bulk density and thickness.

The masses of soil organic matter and nutrients stored per unit area or volume obviously were dependent on soil mass. Masses of soil in genetic horizons or fixed sampling depths were determined by haphazard variations in soil thickness and bulk density, whereas the equivalent soil mass corrected for unjustifiable differences in soil masses. In the absence of information on soil erosion or deposition to justify comparisons among unequal soil masses, comparisons among element masses in an equivalent soil mass were more valid. The effects of management on organic matter and nutrient storage were clarified by eliminating the differences attributable to unequal soil masses. The idea that nutrient masses must be normalized for differences in soil mass is not entirely new, but recent publications indicate a serious and persistent lack of awareness about the influence of soil mass on estimates of nutrient storage.

The impact of management on organic matter storage at the Star City site was obscured by differences in soil bulk density and thickness, and consequently, the masses of the genetic horizons. The impact of management was clarified by calculating the amount of organic matter stored in an equivalent soil mass, which indicated that $\approx 15 \%$ of soil organic $\mathrm{C}$ originally present under forest vegetation was lost after $80 \mathrm{yr}$ of annual cropping. Total $\mathrm{P}$ was closely related to soil mass, and comparisons among masses of total $P$ in the equivalent mass of contrasting soils indicated that the impact of management was minor.

Reassessment of published data indicated that bulk densities of native soils often were less than those of cultivated soils, and native A horizons often were lighter than the cultivated Ap horizons. Thus estimates of organic matter depletion in cultivated soils were greater for calculations based on an equivalent mass than for calculations based on genetic horizons or fixed sampling depths. Bulk densities and masses of no-till soils often were greater than those of conventionally tilled soils. Consequently, estimates of organic matter accumulation in no-till soils were smaller for calculations based on an equivalent mass than for calculations based on genetic horizons or fixed sampling depths.

\section{ACKNOWLEDGMENTS}

Eric Bremer and Henry Janzen provided constructive comments on the manuscript.

Aguilar, R., Kelly, E. F. and Heil, R. D. 1988. Effects of cultivation on soils in northern Great Plains rangeland. Soil Sci. Soc. Am. J. 52: 1081-1085.

Aina, P.O. 1979. Soil changes resulting from long-term management practices in western Nigeria. Soil Sci. Soc. Am. J. 43: 173-177.

Alway, F. J. and Trumbull, R. S. 1910. A contribution to our knowledge of the nitrogen problem under dry farming. J. Indust. Eng. Chem. 2: 135-138.

Ayanaba, A., Tuckwell, S. B. and Jenkinson, D. S. 1976. The effects of clearing and cropping on the organic reserves and biomass of tropical forest soils. Soil Biol. Biochem. 8: 519-525.

Blank, R. R. and Fosberg, M. A. 1989. Cultivated and adjacent virgin soils in northcentral South Dakota: I. Chemical and physical comparisons. Soil Sci. Soc. Am. J. 53: 1484-1490.

Buyanovsky, G. A., Kucera, C. L. and Wagner, G. H. 1987. Comparative analysis of carbon dynamics in native and cultivated ecosystems. Ecology 68: 2023-2031.

Coote, D. R. and Ramsey, J. F. 1983. Quantification of the effects of over 35 years of intensive cultivation on four field soils. Can. J. Soil Sci. 63: 1-14.

Davidson, E. A. and Ackerman, I. L. 1993. Changes in soil carbon inventories following cultivation of previously untilled soils. Biogeochemistry 20: 161-193.

Davidson, J. M., Gray, F. and Pinson, D. I. 1967. Changes in organic matter and bulk density with depth under two cropping systems. Agron. J. 59: 375-378.

De Jong, E. and Kachanoski, R. G. 1988. The importance of erosion in the carbon balance of prairie soils. Can. J. Soil. Sci. 68: 111-119.

Doran, J. W. 1987. Microbial biomass and mineralizable nitrogen distributions in no-tillage and plowed soils. Biol. Fertil. Soils 5: 68-75.

Gregorich, E. G. and Anderson, D. W. 1985. Effect of cultivation and erosion on soils of four toposequences in the Canadian Prairies. Geoderma 36: 343-354.

Henzell, E. F., Fergus, I. F. and Martin, A. E. 1967. Accretion studies of soil organic matter. J. Aust. Inst. Agric. Sci. 33: 35-37. Jenkinson, D. S. and Johnston, A. E. 1976. Soil organic matter in the Hoosfield continuous barley experiment. Pages 87-101 in 
Rothamsted Experiment Station Report for 1976, Part 2. Harpenden, U.K.

Laws, W. D. and Evans, D. D. 1949. The effects of long-time cultivation on some physical and chemical properties of two Rendzina soils. Soil Sci. Soc. Am. Proc. 14: 15-19.

Lawes, J. B. and Gilbert, J. H. 1885. On some points in the composition of soils; with results illustrating the sources of the fertility of Manitoba prairie soils. J. Chem. Soc. XLVII: $380-422$.

Martel, Y. A. et Deschenes, J. M. 1976. Les effets de la mise en culture et de la prairie prolongée sur le carbone, l'azote et la structure de quelques sols due Québec. Can. J. Soil Sci. 56: 373-383.

Newton, J. D., Wyatt, F. A. and Brown, A. L. 1945. Effects of cultivation and cropping on the chemical composition of some western Canada prairie province soils. Part III. Sci. Agric. 25: 718-737.

Nye, P. H. and Greenland, D. J. 1964. Changes in the soil after clearing tropical forest. Plant Soil 21: 101-112.

Post, W. M., Peng, T-H., Emanuel, W. R., King, A. W., Dale, V. H. and DeAngelis, D. L. 1990. The global carbon cycle. Am. Sci. 78: $310-326$.
Powlson, D. S. and Jenkinson, D. S. 1981. A comparison of the organic matter, biomass, adenosine triphosphate and mineralizable nitrogen contents of ploughed and direct-drilled soils. J. Agric. Sci. (Camb.) 97: 713-721.

Roberts, T. L., Bettany, J. R. and Stewart, J. W. B. 1989. A hierarchical approach to the study of organic C, N, P and S in western Canadian soils. Can. J. Soil Sci. 69: 739-749.

Schlesinger, W. H. 1986. Changes in soil carbon storage and associated properties with disturbance and recovery. Pages 194-220 in J. R. Trabalka and D. E. Reichle, eds. The changing carbon cycle - A global analysis. Springer-Verlag, New York, NY.

Slater, C. S. and Carleton, E. A. 1938. The effect of erosion on losses of soil organic matter. Soil Sci. Soc. Am. J. 3: 123-128.

Tiessen, H., Stewart, J. W. B. and Bettany, J. R. 1982. Cultivation effects on the amounts and concentration of carbon, nitrogen, and phosphorus in grassland soils. Agron. J. 74: 831-835. Voroney, R. P., Van Veen, J. A. and Paul, E. A. 1981. Organic $\mathrm{C}$ dynamics in grassland soils. 2. Model validation and simulation of long-term effects of cultivation and rainfall erosion. Can. J. Soil Sci. 61: 211-224. 